\title{
The prevalence of Crohn's disease in the Israeli Kibbutz population
}

\author{
YARON NIV, MD
}

Y NIV. Prevalence of Crohn's disease in the Israeli Kibbutz population. Can J Gastroenterol 1991;5(3):91-93. An epidemiological study of Crohn's disease was performed in 279 Israeli Kibbutzim (rural communities) (population 121,403). The prevalence on December 31,1987 was 25.53 per 100,000 population. When the data were stratified according to ethnic group, the highest point prevalence was found in Asian/African-born Jews (41.76 per 100,000 population), greater than in Israeli-born, or European/American-born Kibbutz members (38.92 and 17.35 cases per 100,000 population, respectively). There were 15 women and 16 men (female to male ratio 0.94). The average age of patients was 45 years in the survey year, and 35 years at diagnosis. Terminal ileitis was found in $69 \%$, ileocolitis in $19 \%$, and colitis in 12\%. Probable complications of Crohn's diseave were observed in 10 cases (32\%). Anemia was demonstrated in two cases $(6 \%)$. The high rate of Crohn's disease prevalence among Israeli-born versus European/American-born Kibbutz members may point to a role for environmental factors in the etiology of the disease.

Key Words: Crohn's disease, IBD, Prevalence

\section{Prévalence de la maladie de Crohn dans la population du kibboutz israélien}

RESUME: On a effectué une étude épidémiologique sur la maladie de Crohn dans 279 kibboutzim ou fermes collectives (soit une population de 121403 personnes). Le 31 décembre 1987, la prévalence était de 25,53 pour 100000 habitants. Selon les données stratifiées d'après les groupes ethniques, les cas les plus nombreux se trouvaient parmi les Juifs d'origine africaine/asiatique $(41,76$ pour 100000 habitants), comparés aux Israéliens d'origine ou aux membres natifs d'Europe ou d'Amérique ( 38,92 et 17,35 cas pour 100000 habitants, respectivement). Il y avait 15 femmes et 16 hommes (rapport de 0,94). L'âge moyen des patients était de 45 ans pendant l'année de l'enquête et de 35 ans au moment du diagnostic. Soixante-neuf pour cent des malades souffraient d'une iléite terminale, $19 \%$ d'une iléocolite, et $12 \%$ d'une colite. On a relevé des complications probables de la maladie de Crohn dans 10 cas (32\%). Deux cas (6\%) présentaient une anémie. Le taux de prévalence élevé de la maladie de Crohn chez les membres des kibboutzim natifs d'Israël, par rapport aux personnes originaires d'Europe et d'Amérique, laisse soupçonner le rôle de certains facteurs environnementaux dans l'étiologie de la maladie.

Gastroenterology Unit, Rebecca Sieff Government Hospital, Safed, Israel

Correspondence and reprints: Dr Y Niv, Gastroenterology Unit, Rebecca Sieff Government Hospital, Safed, Israel

Received for publication January 3, 1991. Accepted March 25, 1991
$\mathrm{T}$ HE PREVALENCE OF CROHN'S DISease varies in different areas of the world, and is reported to be high among peoples of European origin. The high and variable incidence and prevalence of Crohn's disease in Jews can possibly be explained by an interaction of genetic and environmental factors. In all countries surveyed the prevalence is 10 to 70 cases per 100,000 population, three to eight times more common among Jews compared to non-Jews (112). An overall increase in incidence and prevalence in many recent studies was shown for Crohn's disease (13-15). In Israel, Crohn's disease is four times more prevalent among Ashkenazi Jews than among non-Ashkenazim, with a greatly increased frequency among Israeli Jews born in Europe or the United States. Nevertheless, the prevalence in the latter group is three to 10 times lower than among Jews living outside Israel (16-20).

As a high incidence and prevalence of ulcerative colitis was found in members of a Kibbutz (an Israeli rural community) (21), a survey of all of the Kibbutzim in Israel was performed to determine the Crohn's disease point prevalence in this particular population.

\section{PATIENTS AND METHODS}

A community-based survey was conducted. The local physician of every Kibbutz was addressed by mail and telephone and his or her agreement to participate in this survey was obtained. A questionnaire concerning Crohn's 
TABLE 1

Point prevalence of Crohn's disease in the Kibbutz population of Israel (1987)

\begin{tabular}{lccc}
\hline & $\begin{array}{c}\text { Population } \\
\text { base }\end{array}$ & $\begin{array}{c}\text { Crohn's disease } \\
\text { cases }\end{array}$ & $\begin{array}{c}\text { Prevalence } \\
\text { (cases/100,000 population) }\end{array}$ \\
\hline Sex & & & 26.49 \\
Men & 60,400 & 16 & 24.59 \\
Women & 61,003 & 15 & 38.92 \\
Origin & & & 41.76 \\
$\quad$ Israel & 30,831 & 12 & 17.35 \\
Asia/Africa & 7.184 & 3 & 35.50 \\
Europe/America & 74.938 & 13 & 25.53 \\
$\quad$ Unknown & 8,450 & 3 & \\
Total & 121.403 & 31 & \\
\hline
\end{tabular}

TABLE 2

Clinical data

\begin{tabular}{lr}
\hline Number of patients & 31 \\
Age (years) & 45 \\
Average & 11 to 76 \\
Range & 10 \\
Disease duration (years) & 1 to 29 \\
Average & 11 \\
Range & 2 \\
Extent of inflammatory process (cases) \\
Terminal ileitis & 3 \\
Colitis & 15 \\
Ileocolitis & 2 \\
Unknown & \\
Diagnosis during surgery &
\end{tabular}

\section{TABLE 3}

Complicaitons and associated syndromes (cases)

\begin{tabular}{ll}
\hline Anemia (hemoglobin $<10 \mathrm{~g} / \mathrm{dL}$ ) & 2 \\
Sacroileitis & 1 \\
Ankylosing spondylitis & 1 \\
Pyoderma gangrenosum & 1 \\
Rectovaginal fistula & 1 \\
lleocecal fistula & 1 \\
Anal fistula & 1 \\
Anal abscess & 1 \\
Stomatitis aphtoza & 1 \\
Duodenal ulcer & 1 \\
Hyperthyroidism & 1 \\
\hline
\end{tabular}

\section{TABLE 4 \\ Treatment of Crohn's disease (cases)}

\begin{tabular}{lr}
\hline Medical & 10 \\
Systemic steroids & 7 \\
Salazopyrine & 4 \\
Metronidazole & 2 \\
Azathioprine & 3 \\
Systemic steroids + salazopyrine & 3 \\
Systemic steroids + metronidazole & 1 \\
Systemic steroids + azathioprine & 1 \\
Salazopyrine + metronidazole & 2 \\
No medical therapy & 1 \\
Surgical & \\
Partial resection of terminal ileum & 2 \\
Appendectomy & 2 \\
Thyroidectomy & 1 \\
Vagotomy and pyloroplasty & 1 \\
Gastric partitioning & 1 \\
\hline
\end{tabular}

disease patients was then sent to the physician, including information on sex, age, origin, place of diagnosis and follow-up, extent of the inflammatory process, clinical spectrum, therapy, complications of the disease and treatment. Ninety-nine per cent of the addressed physicians cooperated with the author and completed and returned the questionnaire. Information on the population was obtained from the Kibbutz clinic, since all Kibbutz members are insured for medical purposes by the same company. December 31, 1987 was designated as the point prevalence date. When calculating prevalence butzim was considered at risk; denominator data on ethnic groups were derived from Kibbutz clinic records. All patients diagnosed as suffering from Crohn's disease and who were residents of the Kibbutz on December 31, 1987 were included in determination of prevalence. Only cases with a definite diagnosis of Crohn's disease made in a recognized hospital gastroenterology unit were accepted into the study. The data were collected and investigated by the author, and when incomplete, the family physician was again contacted. The data were studied carefully to ensure that no patient with Crohn's disease represented a duplicate case.

\section{RESULTS}

General demographic data: The total population of 279 Kibbutzim on the prevalence day was 121,403 Jewish residents. Stratification by place of birth was Europe/America $62 \%$, Israel 25\%, and Asia/Africa 6\% (Table 1). rates, the entire population of the Kib-
Prevalence: Thirty-six Crohn's disease patients were residents of the Kibbutzim on the prevalence day. Patients who did not fulfill residency criteria (three tem. porary residents) and those whose diag. noses were not confirmed in a gastroenterology clinic (two cases) were excluded.

Thus, 31 cases were included in the study (Table 1). There were 15 women and 16 men (female to male ratio 0.94). The prevalence was 25.53 per 100,000 population. The prevalence in men was slightly higher than that in women. A breakdown of prevalence rates by ethnic group is given in Table 1 . The highest prevalence was demonstrated in Asian/African-born Kibbutz members and, in decreasing order, in Israeliborn and European/American-born Kibbutz members.

Clinical data: The average age of patients in the year of this survey was 45 years, and at the time of diagnosis 35 years (Table 2). Terminal ileitis was found in $69 \%$, ileocolitis in $19 \%$, and colitis in $12 \%$. Probable complications of Crohn's disease were observed in 10 cases (32\%) (Table 3). Anemia was demonstrated in two cases $(6 \%)$. Therapy is described in Table 4. Complications or side effects of therapy were not demonstrated.

\section{DISCUSSION}

Roth et al (22) suggested that American Jewish patients with inflam. matory bowel disease represented a nonrandom genetically predisposed subset of the Jewish population. They found a significant excess of patients of middle European origin relative to those of Polish or Russian origin. The genetic influence is not supported by Fireman et al (13), who found a decrease in difference between prevalence of original migrant groups in Israeli Jews of central Israel. The prevalence in European/Americanborn Jews increased from 13.27 to 26.05 cases per 100,000 population, and in Asian/African-born Israeli Jews from 1.69 to 12.37 cases per 100,000 population from 1970 to 1980 (1.96. fold versus 7.32-fold, respectively). Thus, the increase of Crohn's disease prevalence in Asian/African-born Is. 
raeli Jews was almost four times that in European/American-born Israeli Jews. Asian/American-born Kibbutz members had a higher point prevalence of Crohn's disease than the others, and the prevalence rate in Israeli-born members exceeded that in European/ American-born members. However, most of the Israeli-born Kibbutz members were of European/American origin, either first or second generation in Israel. Thus, it is not clear whether environmental factors play a more important role than genetic factors. Since the peak incidence of Crohn's disease occurs in the second and third decades of life, and European/American- and Asian/African-born groups may be older than Israeli-born patients, these results become even more significant.

The present survey is a communitybased study, and includes most of the patients with proven Crohn's disease in

\section{REFERENCES}

1. Acheson ED. The distribution of ulcerative colitis and regional enteritis in United States veterans with particular reference to the Jewish relision. Gut 1960;1:291-3.

2. Evans JG, Acheson ED. An epidemiological study of ulcerative colitis and regional enteritis in the Oxford area. Gut 1965;6:311-24.

3. Monk M, Mendeloff Al, Siegel CI, Lilienfeld A. An epidemiological study of ulcerative colitis and regional enteritis among adults in Baltimore. I. Hospital incidence and prevalence; 1960 to 1963 . Gastroenterology 1967;53:198-210.

4. Monk M, Mendeloff AI, Siegel C. An epidemiological study of ulcerative colitis and regional enteritis among adults in Baltimore. II. Social and demographic factors. Gastroenterology 1969;56:847-57.

5. Gelpi AP. Inflammatory bowel disease among college students. West J Med 1973;129:369-73.

6. Mendeloff AI. The epidemiology of inflammatory bowel disease. Clin Gastroenterol 1980;9:259-69.

7. Sedlack RE, Whisnant J, Elveback LR. Incidence of Crohn's disease in Olmsted county. Minn J Epidemiol 1980;112:759-62.

8. Calkins BM, Lilienfeld AM, Grasland $\mathrm{CF}$. Trends in the incidence rates of a given population. As the level of medical care in the Kibbutz is somewhat above average Israeli family medicine, and as every Kibbutz has its own clinic, the author believes that almost every Crohn's disease case could be traced. People with known Crohn's disease cannot become members of a Kibbutz, since the criteria for accepting new members are very strict, and include 'perfect health'. The high prevalence noted in this study may relate also to the very steady Kibbutz population allowing inclusion of some cases with delayed diagnoses. Some cases may possibly have been added in a colorectal screening program of fecal occult blood testing, as secondary prevention of cancer is very popular in the Kibbutzim. Mayberry et al (23) found two cases of Crohn's disease out of 481 patients screened via fecal occult blood test.

ulcerative colitis and Crohn's disease. Dig Dis Sci 1984;29:913-20.

9. Mayberry JF, Rhodes J.

Epidemiological aspects of Crohn's disease: A review of the literature. Gut 1984;25:886-99.

10. Calkins BM, Mendeloff AI. Epidemiology of inflammatory bowel disease. Epidemiol Rev 1986;8:60-91.

11. Sonnenberg A. Geographic variation in the incidence of and mortality from inflammatory bowel disease. Dis Colon Rectum 1986;29:854-7.

12. Whelan G. Epidemiology of inflammatory bowel disease. Med Clin North Am 1990;74:1-12.

13. Fireman Z, Grossman A, Lilos P, Eschar Y, Theodore E, Gilat T. Epidemiology of Crohn's disease in the Jewish population of central Israel. Am J Gastroenterol 1989;84:255-8.

14. Fellows IW, Mayberry JF, Holmes GK. Crohn's disease in West Indians. Am ] Gastroenterol 1988;83:752-5.

15. Rose JD, Roberts GM, Williams G, Mayberry JF, Rhodes J. Cardiff Crohn's disease jubilee: The incidence over 50 years. Gut 1988;29:346-51.

16. Rozen P, Zonis J, Yekutiel P, Gilat T. Crohn's disease in the Jewish population of Tel-Aviv Yafo. Gastroenterology 1979;76:25-30.

17. Gilat T. Incidence of inflammatory bowel disease: Going up or down? Gastroenterology 1983;65:196-203.
Only two patients $(6.5 \%)$ required surgery in a mean follow-up of 10 years. This percentage is very low and may demonstrate the conservative therapeutic approach towards Crohn's dis. ease in Israel.

The author could not find any cases of cancer after an average disease duration of 10 years. This finding is in agreement with another Israeli population-based survey, which found only one case of cancer in 365 cases of Crohn's disease (24).

The author suggests that the increase in Crohn's disease prevalence in Israeli-born Jewish Kibbutz members provides some support for environmental factors playing a role in disease expression. Ethnic groups merging into a homogeneous people become similar in their food and life patterns, and the epidemiological characteristics of Crohn's disease may change accordingly.

18. Gilat T, Grossman A, Fireman Z, Rozen P. Inflammatory bowel disease in Jews. Front Gastrointest Res 1986;11:135-40.

19. Grossman A, Fireman Z, Lilos P, Hacohen D, Gilat T. Epidemiology of IBD in central Israel 1970-1980. Israeli Gastroenterological Association, Herzlia 1987. (Abst)

20. Donaldson RM Jr. Crohn's disease. In: Sleisenger MH, Fordtran IS, eds. Gastrointestinal Diseases, 4th edn. Philadelphia: WB Saunders, 1989:1327

21. Niv Y, Abuksis G. The prevalence of ulcerative colitis in the Israeli Kibbutz population. J Clin Gastroenterol. (In press)

22. Roth MP, Petersen GM, McElree C, Feldman E, Rotter JI. Geographic origins of Jewish patients with inflammatory bowel disease. Gastroenterology 1989;97: 00-4.

23. Mayberry JF, Ballantyne KC, Hardcastle JD, Mangham C, Pye G. Epidemiological study of asymptomatic inflammatory bowel disease: The identification of cases during a screening programme for colorectal cancer. Gut 1989;30:481-3.

24. Fireman Z, Grossman A, Lilos P, et al. Intestinal cancer in patients with Crohn's disease. A population study in central Israel. Scand J Gastroenterol 1989;24:346-50. 


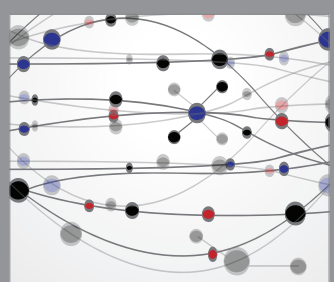

The Scientific World Journal
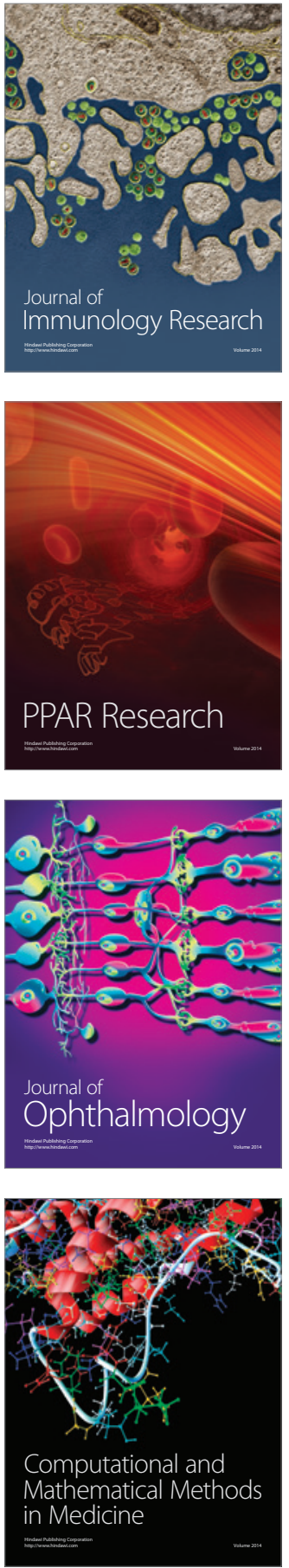

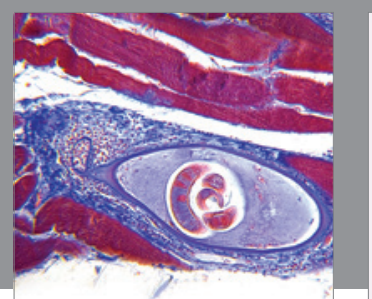

Gastroenterology Research and Practice

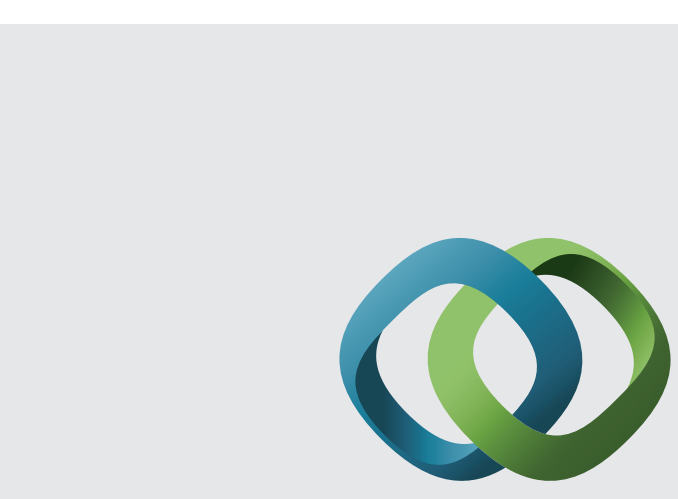

\section{Hindawi}

Submit your manuscripts at

http://www.hindawi.com
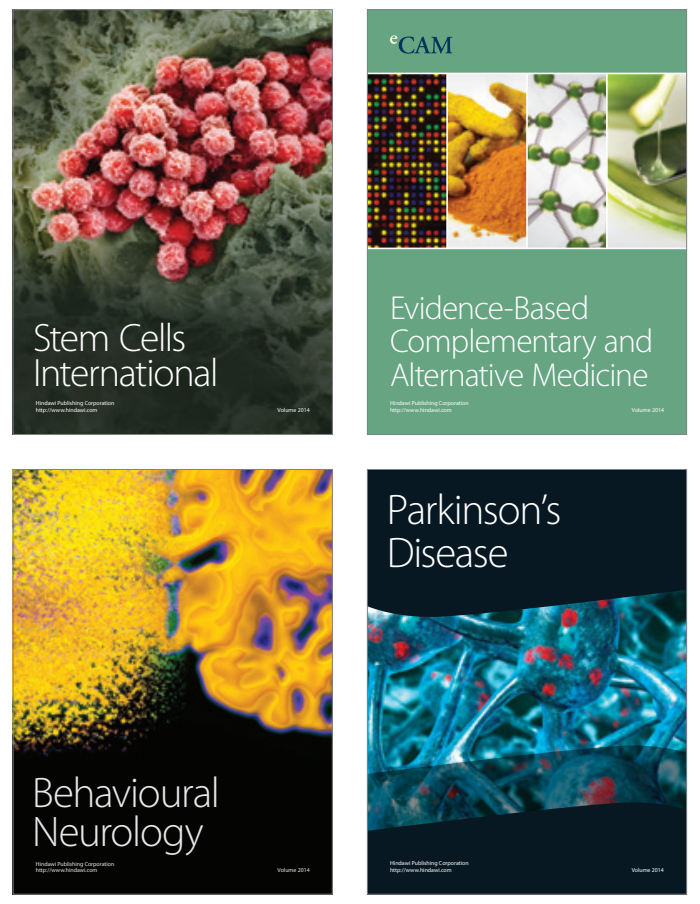
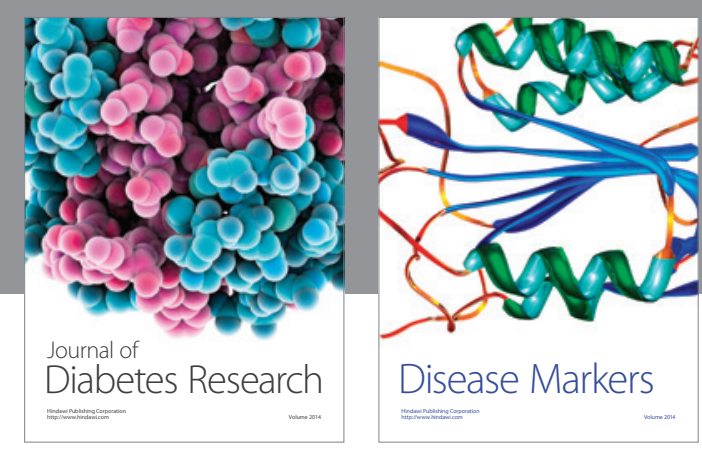

Disease Markers
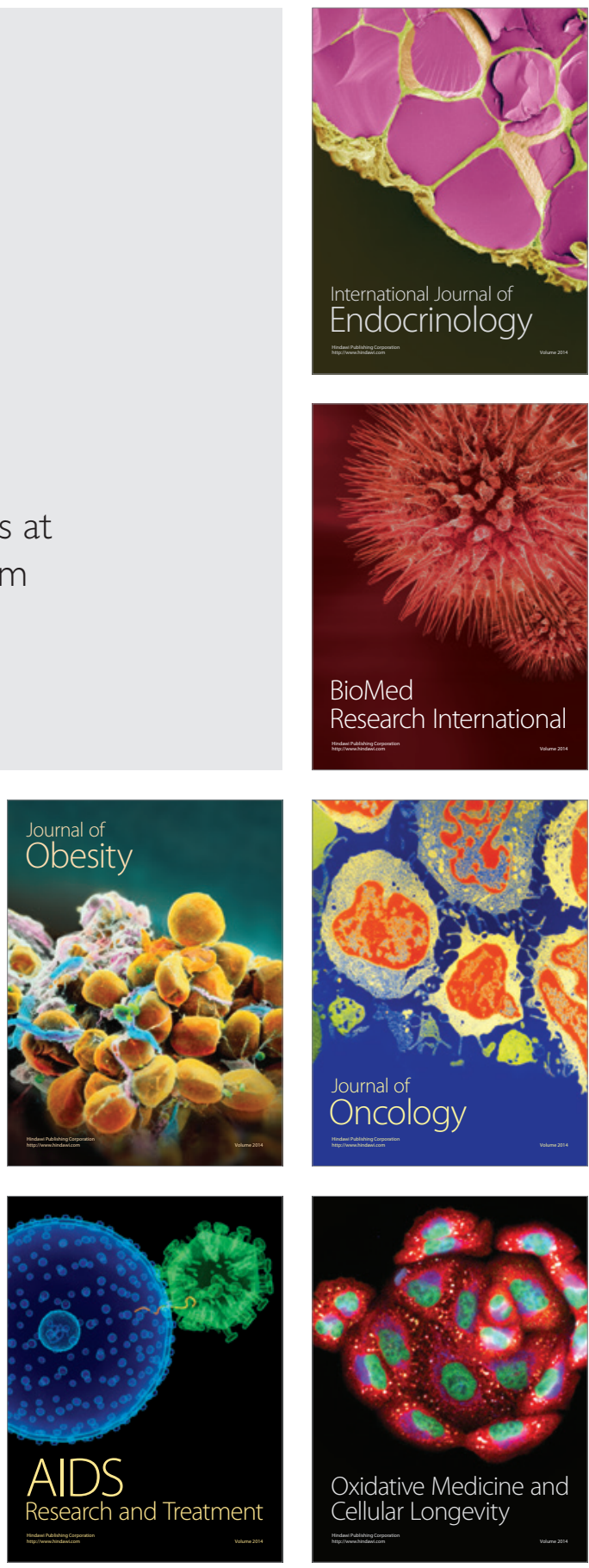